\title{
Otolaryngologic Mucosal Immune Compartments
}

\section{Ibrahim MS Shnawa* \\ College of Biotechnology, University of Qasim, Iraq}

*Corresponding author: Ibrahim MS Shnawa, College of Biotechnology, University of Qasim, Qasim, Iraq, Tel: 07800188929; E-mail: ibrahimshnawa3@gmail.com

\section{Editorial}

Volume 2 Issue 1

Received Date: February 2, 2017

Published Date: March 06, 2017

DOI: $10.23880 /$ ooaj-16000147

\section{Editorial}

Nose, Ear, and Tonsils are the anatomic compartments that functions in respiration, hearing and swallowing accordingly. Nasal mucosa, ear internal surface mucosa and wax as well as the glandular tissues of the tonsils are parts of the common mucosal immune system. They constitute an inductive site for the mucosal immune responses. Mucosal immunoglobulins, mucosal macrophages, mucosal $\mathrm{T}$ helpers, and mucosal $\mathrm{B}$ lymphocytes are the main players in the local immune responses in these compartments [1]. The total microbial entities in these compartments, the microbiome [2] interplayed an integral roles in maintaining compartmental homeostasis, mucosal protection there in the commensal parts of the microbiome may played the role of the balance to the intruding microbial pathogens and might produce secondary metabolite of an indispensable importance to the biochemic and immunobiologic mechanisms. Focusing on nasal compartment [NC]. NC served several biologic and immunobiologic functions which are depicted in (Table 1). The collective personal experience on the nasal mucosal vaccination at the levels of laboratory animal models have shown that the systemic immune response to mucosally applied bacterial and/or allergens, (Tables 2 $\& 3$ ), were of variable degrees depending on the nature of the applied bacterin or allergen. Thus infection, vaccination, infection and vaccination as well as the inhaled allergens were the main inducers to the local nasal immune responses and mucosal allergy which might be terminated by the rising of the allergic nasal polyps [3]. Common cold and /or bacterial pathogens may initiate the cascade of infection cycle up to allergic rhinitis. So to draw a conclusion to the welfare of layman in the underdeveloped, developing and developed countries, be aware of getting common cold and of the exposure to an indoor or outdoor infectious agents and/or allergens.

\begin{tabular}{|c|}
\hline Biologic Functions \\
\hline Balancing the asthetic compartment of human face \\
\hline Exhalation of CO2,Inhalation of O2 \\
\hline Inhalation of perfumes \\
\hline Inhalation of nasty odors \\
\hline The Mucosal Immunobiologic Functions \\
\hline It constitute the NALT compartment of the CMIS \\
\hline Site for induction of mucosal immune responses \\
\hline Site for allergenic reactions \\
\hline $\begin{array}{c}\text { It serves as a niche for the microbial succession initiated } \\
\text { in the nasal mcirobiome }\end{array}$ \\
\hline
\end{tabular}

Table 1: Nasal biologic and immunobiologic functions.

\begin{tabular}{|c|}
\hline Infection \\
\hline Vaccination \\
\hline Infection and vaccination \\
\hline Inhaled allergens \\
\hline
\end{tabular}

Table 2: Nature of the nasal mucosal immune response inducers.

\begin{tabular}{|c|c|c|}
\hline Bacterial type & $\begin{array}{c}\text { Mucosal Immune } \\
\text { Induction/systemic } \\
\text { conc. mglml. of } \\
\text { cryoglobulin }\end{array}$ & References \\
\hline M. & 39,32 & $\begin{array}{c}\text { Shnawa \& } \\
\text { Jassim [4] }\end{array}$ \\
\hline tuberculosis/BCG & 18.51 & $\begin{array}{c}\text { Shnawa \& } \\
\text { Alserhan [5] }\end{array}$ \\
\hline Salmonella typhi & 6.33 & $\begin{array}{c}\text { Shnawa \& } \\
\text { Jassim [6] }\end{array}$ \\
\hline
\end{tabular}

Table 3: The potency variations in the lapin nasal mucosal vaccination. 


\section{Otolaryngology Open Access Journal}

\section{References}

1. Shnawa IMS (2013) Mucosal Immunology, Lap Lambert Academic Publication.

2. Bassias CM, Tang AL, Young VB, Pynnonen MA (2014) The nasal cavity microbiota of healthy adults. Microbiome 2: 27.

3. Shnawa IMS, Adoose SA, Hussian AM (2006) A nine years Mass Surveillance for the Allergic Nasal Polyp. KUfa Med J 9(1): 135-139.
4. Shnawa IMS, Jassim YA (2016) Lapin cryoglobulin responses to Brucella meletensis RV-1. IJAPBC 5(3): 341-345.

5. Shnawa IMS, ASL Serhan AJ (2014) The immune features of Salmonella typhi somaic antigen induced lapin cryglobulinemia. Inter J Curr Res 6(10): 90659068.

6. Shnawa IMS, Jassim YA (2011) BCG and Tuberculin induced experimental lapin secondary cryoglobulinemia. QMJ 7(12): 209-219. 